\title{
Pengaruh Takaran Pupuk Kandang Sapi Terhadap Pertumbuhan dan Hasil Jagung (Zea mays, L.) yang Ditumpangsarikan dengan Kedelai (Glysine max, (L.) Merril)
}

\author{
Wendalinus Leki ${ }^{\mathrm{a}}$, Maria Afnita Lelang ${ }^{\mathrm{b}}$, Roberto I. C. O. Taolin ${ }^{\mathrm{c}}$ \\ ${ }^{a}$ Fakultas Pertanian, Universitas Timor, Kefamenanu, TTU - NTT, 85613, Indonesia. \\ ${ }^{\mathrm{b}}$ Fakultas Pertanian, Universitas Timor, Kefamenanu, TTU - NTT, 85613, Indonesia, email: afnitalelang@ymail.com \\ c Fakultas Pertanian, Universitas Timor, Kefamenanu, TTU - NTT, 85613, Indonesia, email: ricotaolin@gmail.com
}

\section{Article Info}

\section{Article history:}

Received 20 Agustus 2015

Received in revised form 29 Agustus 2015

Accepted 28 September 2015

Keywords:

Pupuk Kandang Sapi

Tumpangsari

Jagung

Kedelai

\begin{abstract}
Abstrak
Penelitian ini bertujuan untuk mengetahui pengaruh takaran pupuk kandang sapi terhadap pertumbuhan dan hasil jagung yang ditumpangsarikan dengan beberapa varietas kedelai. Percobaan lapangan telah dilakukan di Kebun Fakultas Pertanian Universitas Timordengan menggunakan Rancangan Acak Kelompok (RAK) faktorial $3 \times 3$ diulang dalam 3 blok. Faktor yang diteliti adalah takaran pupuk kandang sapi yang terdiri dari tiga aras yaitu tanpa pupuk, $30 \mathrm{t} / \mathrm{ha}$ dan $40 \mathrm{t} / \mathrm{ha}$. Faktor kedua adalah varietas kedelai yang terdiri dari tiga aras yaitu Davros, Willis dan Lokal. Hasil penelitian menunjukkan tidak terjadi pengaruh interaksi antara takaran pupuk kandang sapi dan varietas kedelai terhadap semua parameter yang diamati.Takaran pupuk kandang sapi berpengaruh secara nyata terhadap suhu tanah 75 HST, kadar lengas 50 HST, diameter batang 25 HST, jumlah biji per baris, berat kering 100 biji, berat kering biji per petak dan indeks panen. Varietas kedelai berpengaruh secara nyata terhadap jumlah baris per bulir, jumlah biji per baris dan berat kering biji per petak.Pupuk kandang sapi 40 t/ha merupakan takaran yang lebih baik dan kedelai varietas Lokal lebih cocok untuk ditumpangsarikan dengan jagungpulut dengan hasil jagung 1,0 t/ha dan kedelai 0,7 t/ha. @2016 dipubikasikan oleh Savana Cendana.
\end{abstract}

\section{Pendahuluan}

Upaya untuk meningkatkan produktivitas lahan dapat dilakukan melalui pertanaman secara tumpangsari (intercropping system), karena dapat memelihara kelembaban dan kadar air tanah serta mengurangi erosi dan meningkatkan kesuburan tanah (Warsono, 1998). Beberapa keuntungan dari sistem tumpangsari antara lain pemanfaatan lahan kosong di sela-sela tanaman pokok, peningkatan produksi total persatuan luas karena lebih efektif dalam penggunaan cahaya, air serta unsur hara, disampingdapat mengurangi resiko kegagalan panen dan menekan pertumbuhan gulma (Herlina, 2011)

Jagung (Zea mays, L.) umumnya merupakan tanaman utama yang banyak dibudidayakan di lahan kering. Kandungan gizi utama jagung yaitu protein 4,1 g, lemak 1,3 g, karbohidrat 30,3 g, kalsium 5,0 mg, fosfor 108,8 mg, besi 1,1 $\mathrm{mg}$ dan air 63,5 g. Produksi jagung di Indonesia masih rendah, sehingga kebutuhan dalam negeri masih dipenuhi dengan impor yaitu sebanyak 1 juta ton per tahun (Nasution, 2004).

Produksi jagung di Kabupaten Timor Tengah Utara dari tahun 2010 hingga 2013 mengalami peningkatan dimana pada tahun 2010 produksi tanaman jagung mencapai 54.027 ton dan pada tahun 2013 meningkat 63.677 ton (Dinas Pertanian Tanaman Pangan Propinsi Nusa Tenggara Timur, 2010).

Di pulau Timor budidaya tanaman pangan seperti jagung selain penanaman secara monokultur juga secara tumpangsari bersama dengan komoditas tanaman lain seperti padi ladang, kedelai, ubi kayu, kacang tanah, kacang gude (kacang turis), kacang hijau, mentimun dan jewawut. Tanaman kedelai dan jagung memungkinkan untuk ditumpangsarikan karena tanaman jagung membutuhkan nitrogen tinggi, sementara kedelai dapat memfiksasi nitrogen dari udara bebas sehingga kekurangan nitrogen pada jagung terpenuhi oleh kelebihan nitrogen pada kedelai (Jumin, 1997). Kombinasi kedelai dan jagung sangat serasi, hal ini berhubungan dengan kompatibilitas beberapa sifat yang dimiliki oleh kedua jenis tanaman ini, dimana kedelai termasuk tanaman golongan $\mathrm{C} 3$ yang cukup toleran terhadap naungan yang mempunyai akar tunggang dan membentuk bintil akar yang mampu menfiksasi N2 secara simbiosis dengan bakteri Rhizobium sp, sedangkan jagung tergolong tanaman $\mathrm{C} 4$ yang membutuhkan pencahayaan secara langsung dan membutuhkan unsur hara yang besar terutama unsur N.

Kedelai merupakan salah satu komoditas tanaman pangan yang memegang peranan penting di Indonesia, karena kedelai memiliki kandngan gizi yang tinggi, yaitu terdiri dari 40-45\% protein, $18 \%$ lemak, $24-36 \%$ karbohidrat, $8 \%$ kadar air, asam amino dan kandungan gizi lainnya yang bermanfaat untuk memenuhi kebutuhan gizi masyarakat. Selain itu, kedelai juga dapat digunakan sebagai bahan baku industri, pakan ternak dan untuk pembuatan minyak (Suprapto, 1998). Kedelai juga mengandung asam-asam tak jenuh yang dapat mencegah timbulnya arteri sclerosis yaitu terjadinya pengerasan pembulu nadi (Taufiq dan Nova, 2004). Kebutuhan terhadap kedelai semakin meningkat dari tahun ke tahun sejalan dengan bertambahnya penduduk dan meningkatkan kesadaran masyarakat terhadap makanan berprotein nabati.

Produksi kedelai secara nasional dalam kurung waktu 2011 hingga 2013 mengalami peningkatan dimana pada tahun 2011 produksi kedelai mencapai 775.710 ton dan pada tahun 2013 mengalami peningkatan sebesar 780.163 ton Produksi kacang kedelai di Nusa Tenggara Timur, khususnya di Kabupaten TTU masih tergolong rendah. Berdasarkan data Survei Pertanian dan Angka Tetap Propinsi NTT, produksi di tahun 2010-2011 hanya mencapai 10,00 ton (BPS, 2011). Keadaan produksi dan produktivitas dari setiap jenis tanaman pangan yang diusahakan di Kabupaten TTU pada umumnya berbeda-beda tergantung pada cara pemeliharaan, luas panen, kondisi struktur tanah, iklim dan curah hujan. Corak usaha tani yang masih bersifat subsistem dan faktor keramahan alam menjadi sangat dominan pengaruhnya terhadap kuantitas dan kualitas produksi. Sesuai kondisi tersebut, pembangunan pertanian yang berwawasan lingkungan dalam rangka menjaga kelestarian ekosistem alam akan terasa sangat bermanfaat untuk kelanjutan usaha tani (BPS,2011).

Kedelai dan Jagung yang ditanam secara tumpangsari akan terjadi kompetisi dalam memperebutkan unsur hara, air dan sinar matahari. Sehingga pengaturan sistem tanam dan pemberian pupuk sangat penting untuk mengurangi terjadinya kompetisi tersebut.

Pemberian pupuk kandang dapat memperbaiki kondisi lingkungan pertumbuhan tanaman yang pada akhirnya mampu meningkatkan hasil produksi suatu tanaman. Bahan organik dapat memperbaiki sifat fisik dan kimia tanah juga dapat meningkatkan jumlah dan aktifitas mikroorganisme tanah (Hsieh dan Hsieh, 1990). Perombakan bahan organik akan menyumbangkan unsur hara yang dikandungnya untuk tanaman. Hasil penelitian Noor dan Ningsih (1998) menunjukkan pupuk kandang kotoran sapi mempunyai kadar $\mathrm{N} 0,92 \%$, $\mathrm{P}$

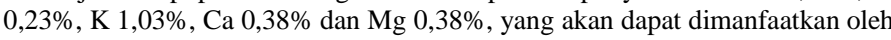
tanaman kalau sudah terurai.

Selain takaran pupuk kandang dan penanaman secara tumpangsari, produktifitas lahan dan tanaman juga dapat ditingkatkan dengan cara penggunaan varietas yang sesuai. Kedelai memiliki berbagai varietas unggul yang memiliki persyaratan tumbuh dan kemampuan produksi yang berbeda Permasalahannya adalah belum diketahui pengaruh takaran pupuk kandang dan varietas kedelai yang tepat untuk ditumpangsarikan dengan jagung, oleh karena itu perlu dilakukan penelitian tentang pengaruh takaran pupuk kandang sapi pada tumpangsari jagung (Zea mays, L.) dengan beberapa varietas kedelai (Glysine max, L.)

Penelitian ini bertujuan untuk mengetahui pengaruh takaran pupuk kandang sapi terhadap pertumbuhan dan hasil jagung yang ditumpangsarikan dengan beberapa varietas kedelai.

\section{Metode}

2.1 Waktu dan Tempat

Penelitian ini dilakukan pada bulan Maret - Juli 2015 di Kebun Fakultas Pertanian Universitas Timor, Kelurahan Sasi Kecamatan Kota Kefamenanu, Kabupaten Timor Tengah Utara, Provinsi Nusa Tenggara Timur, topografi berbukit dengan ketinggian 300-400 m dpl curah hujan 900-1500 mm per tahun, suhu udara berkisar antar $22-35^{\circ} \mathrm{C}$ dan $\mathrm{pH} 6,5$ (BPS TTU, 2011).

2.2 Rancangan Percobaan

Percobaan lapangan menggunakan Rancangan Acak Kelompok (RAK) faktorial $3 \times 3$. Faktor yang diteliti adalah takaran pupuk kandang sapi $(\mathrm{K})$ yang terdiri dari tiga aras yaitu tanpa pupuk $\left(\mathrm{k}_{1}\right), 30 \mathrm{t} / \mathrm{ha}\left(\mathrm{k}_{2}\right)$ dan $40 \mathrm{t} / \mathrm{ha}\left(\mathrm{k}_{3}\right)$. Faktor kedua adalah varietas kedelai $(\mathrm{V})$ yang terdiri dari tiga aras yaitu Davros $\left(\mathrm{v}_{1}\right)$, Willis $\left(\mathrm{v}_{2}\right)$ dan Lokal $\left(\mathrm{v}_{3}\right)$. Dengan demikian terdapat sembilan kombinasi perlakuan dengan tiga ulangan sehingga terdapat 27 satuan percobaan Kombinasi perlakuannya adalah $\mathrm{k}_{1} \mathrm{v}_{1}, \mathrm{k}_{1} \mathrm{v}_{2}, \mathrm{k}_{1} \mathrm{v}_{3}, \mathrm{k}_{2} \mathrm{v}_{1}, \mathrm{k}_{2} \mathrm{v}_{2}, \mathrm{k}_{2} \mathrm{v}_{3}, \mathrm{k}_{3} \mathrm{v}_{1}, \mathrm{k}_{3} \mathrm{v}_{2}$ dan $\mathrm{k}_{3} \mathrm{~V}_{3}$.

2.3 Pelaksanaan Penelitian

a. Persiapan benih

Benih yang digunakan dalam penelitian ini adalah benih jagung lokal yang diambil dari Kabupaten Malaka Desa Kletek yang bebas dari hama dan penyakit serta benih kacang kedelai yang dibeli di BPTP Naibonat. Jumlah benih jagung yang dibutuhkan dalam penelitian ini sebanyak 1.296 biji dan benih kacang kedelai yang dibutuhkan dalam penelitian ini sebanyak 972 biji. b. Persiapan lahan

Sebelum pengolahan tanah dilakukan, terlebih dahulu gulma dibersikan dengan mengunakan tofa dan parang. Pengolahan tanah dilakukan dengan menggunakan linggis dan pacul, tanah dibalik, dihancurkan dibiarkan selama satu minggu dilanjutkan dengan pembuatan bedeng dan diberi label sesuai perlakuan. Ukuran petak percobaan yaitu panjang $420 \mathrm{~cm}$ dan lebar $210 \mathrm{~cm}$ 


\section{c. Pemupukan}

Pupuk kandang sapi diberikan pada petak perlakuan lima minggu sebelum tanam dengan cara dibenamkan kedalam tanah.Pada sembilan bedeng diberikan pupuk kandang sebanyak $19,8 \mathrm{~kg}$ per petak dan pada sembilan bedeng lainnya diberikan pupuk kandang sapi sebanyak $26,4 \mathrm{~kg}$ per petak, sedangkan sembilan bedeng tidak diberikan pupuk kandang sapi. Jumlah pupuk kandang sapi yang diberikan dalam penelitian ini adalah 415,8 kg.

d. Penanaman

Jagung ditanam bersamaan dengan kacang kedelai, secara tumpangsari dengan model selang-seling (Nahak, 2013). Penanaman dilakukan dengan menggunakan tugal dan setiap lubang tanam diisidua biji. Jarak tanam yang digunakan adalah $70 \mathrm{~cm} \times 35 \mathrm{~cm}$, sehingga jumlah tanaman dalam setiap petak adalah 42 tanaman dan jumlah tanaman keseluruhan adalah 1.134 tanaman.

e. Pemeliharaan

Pemeliharaan yang dilakukan berupa penyiraman dan penyiangan. Penyiraman dilakukan pada setiap pagi hari dan sore hari dengan menggunakan gembor atau ember, selanjutnya diikuti dengan penyulaman terhadap bibit yang mati atau rusak pada saat tanaman berumur 10 hari setelah tanam (HST). Cara penyulaman adalah mengganti bibit yang mati atau rusak dengan menggunakan bibit cadangan yang sudah disiapkan.Penyiangan pertama dilakukan pada saat tanaman berumur tiga minggu dan penyiangan kedua dilakukan pada saat tanaman berumur delapan minggu dan alat yang digunakan dalam penyiangan adalah tofa.

f. Panen

Panen dilakukan saat jagung dan kedelai berumur 90 HST. Panen jagung dilakukan dengan cara dipatah pulirnya dan dimasukan ke dalam kantong plastik yang sudah diberi label. Panen kedelai dilakukan dengancara dipetik dan dimasukan kedalam kantok plastik yang telah diberi label.

2.4 Parameter Pengamatan

a. Suhu Tanah $\left({ }^{\circ} \mathrm{C}\right)$

Suhu tanah diukur saat tanaman berumur 25 HST, 50 HST dan 75 HST suhu tanah dicacat setelah 2-3 menit termometer suhu tanah ditancapkan ke dalam tanah sedalam $5 \mathrm{~cm}$. Pengukuran dilakukan pada tiga titik dalam setiap petak dan dilakukan pada siang hari pukul 12.00 - 13.00 WITA.

b. Kadar Lengas Tanah (\%)

Kadar lengas tanah diukur tiga kali selama penelitian yakni 25 HST, 50 HST dan 75 HST. Kadar lengas tanah diukur dengan metode gravimetrik. Contoh gumpalan tanah dengan diameter $\pm 2 \mathrm{~cm}$ yang diambil di tiga titik di setiap petak, ditimbang berat basahnya (A),dioven pada suhu $105-110^{\circ} \mathrm{C}$ selama 24 jam atau sampai berat konstan, kemudian ditimbang berat keringnya (Nahak, 2013). Kadar lengas tanah dihitung dengan rumus : (Anonim, 2005).

$$
\begin{array}{cl} 
& \multicolumn{1}{c}{\text { KL }=\frac{\mathrm{A}-\mathrm{B}}{\mathrm{B}} \times 100 \%} \\
\text { Keterangan } & : \\
\text { KL } & : \text { Kadar Lengas Tanah }(\%) \\
\text { A } & \text { : Berat Basah Tanah }(\mathrm{g}) \\
\text { B } & : \text { Berat Kering Tanah }(\mathrm{g})
\end{array}
$$

c. Berat Volume Tanah $\left(\mathrm{g} / \mathrm{cm}^{3}\right)$

Berat volume tanah diukur tiga kali selama penelitian yakni $25 \mathrm{HST}, 50$ HST dan 75 HST. Sampel tanah gumpalan kering dari pengukuran kadar lengas tanah kemudian diikat dengan benang dan dicelupkan dalam cairan lilin dalam wadah alumanium yang telah dipanaskan dengan lampu spritus. Bongkahan tanah yang telah dilapisi lilin didinginkan kemudian dimasukan ke dalam gelas ukur yang telah berisi air dengan volume tertentu. Selisih kenaikan permukaan air didalam gelas ukur dicatat sebagai volume bongkahan tanah. Berat volume tanah dihitung dengan rumus : (Poerwowidodo, 1995).

\begin{tabular}{cl} 
& \multicolumn{1}{c}{$\mathrm{BV}=\frac{\mathrm{B}}{\mathrm{V}}$} \\
Keterangan & $:$ Berat Volume Tanah $\left(\mathrm{g} / \mathrm{cm}^{3}\right)$ \\
$\mathrm{BV}$ & $:$ Berat Tanah Kering Oven $(\mathrm{g})$ \\
$\mathrm{B}$ & $:$ Volume Tanah $\left(\mathrm{cm}^{3}\right)$
\end{tabular}

d. Tinggi Tanaman $(\mathrm{cm})$

Tinggi tanaman diukur pada 25 HST, 50 HST dan 75 HST terhadap lima tanaman sampel jagung dan lima tanaman sampel kedelai. Tinggi tanaman diukur dari pangkal batang tepat di permukaan tanah sampai pada bagian tanaman tertinggi dengan menggunakan mistar.

e. Diameter Batang $(\mathrm{mm})$

Diameter batang diukur $3 \mathrm{~cm}$ dari permukaan tanah dan diukur pada 25 HST, 50 HST dan 75 HST terhadap lima tanaman sampel jagung dan lima tanaman sampel kedelai dengan menggunakan jangka sorong.

f. Luas Daun $\left(\mathrm{cm}^{2}\right)$

Pengukuran luas daun dilakukan saat tanaman berumur 75 HST. Pengukuran luas daun dilakukan menggunakan metode fotografi dengan cara mengambil semua daun pada lima tanaman sampel jagung dan lima tanaman sampel kedelai pada tiap petak, kemudian daun dipotret menggunakan kamera digital. Luas area daun kemudian dihitung menggunakan program ImageJ 1.41o

\section{g. Jumlah Bulir Per Tanaman Jagung}

Dilakukan dengan cara menghitung bulir yang dihasilkan setiap tanaman pada lima tanaman sampel.

h. Jumlah Baris Per Bulir Tanaman Jagung

Dilakukan dengan cara menghitung jumlah baris pada setiap bulir lima tanaman sampel jagung.

i. Jumlah Biji Per Baris Tanaman Jagung

Jumlah biji per baris diperoleh dengan cara menghitung semua biji dalam baris pada setiap tongkol tanaman sampel kemudian dirata-ratakan.

j. Jumlah Polong Per Tanaman Kedelai

Dilakukan dengan cara menghitung polong yang terbentuk pada lima tanaman sampel setiap petak.

k. Jumlah Biji Per Polong Kedelai

Dilakukan dengan cara menghitung biji setiap polong pada lima tanaman sampel kacang kedelai.

1. Berat Kering Biji Per Tanaman (g)

Diukur dengan cara menimbang hasil berupa biji dari lima tanaman sampel jagung dan kedelai yang telah dikeringkan selama \pm satu minggu dengan cara dijemur.

\section{m. Berat 100 Biji (g)}

Diukur dengan caramenimbang berat 100 biji tanaman sampel jagung dan kedelai setelah panen dan dikeringkan denganmengunakan timbangan Ohause.

n. Berat Kering Biji Per Petak (t/ha)

Diukur dengan cara menimbang biji kering jagung dan kedelai dari setiap petak perlakuan dengan menggunakan timbangan Ohause kemudian di konversian ke t/ha.

o. Berat Segar Brangkasan (t/ha)

Diukur dengan cara menimbang berangkasan segar tanaman jagung dan kedelai pada setiap petak.

p. Berat Kering Brangkasan ( $\mathrm{t} / \mathrm{ha}$ )

Diukur dengan cara menimbang berangkasan tanaman jagung dan kedelai pada setiap petak yang telah dikeringkan dengan cara penjemuran selama satu minggu.

\section{q. Indeks Panen $(\%)$}

Dihitung dengan cara membandingkan berat bagian tanaman yang bernilai ekonomis per petak dengan berat seluruh bagian tanaman (non ekonomis) per petak kemudian dikonversikan ke satuan \%. Indeks panen dihitung untuk tanaman jagung dan kedelai dengan rumus :

$$
\mathrm{IP}=\frac{\mathrm{BE}}{\mathrm{BE}+\mathrm{BNE}} \times 100 \%
$$

\begin{tabular}{ll} 
Keterangan & \multicolumn{1}{c}{$:$} \\
IP & $:$ Indeks Panen \% \\
BE & $:$ Berat Biji Per Petak (t/ha) \\
BNE & $:$ Berat Kering Berangkasan (t/ha)
\end{tabular}

\subsection{Analisis Data}

Semua data yang diperoleh kemudian ditabulasi dan dianalisis dengan menggunakan sidik ragam (ANOVA) Rancangan Acak Kelompok, selanjutnya rerata perlakuan diuji dengan menggunakan uji Duncan Multiple Range Test (DMRT) dengan tingkat signifikasi 5\% sesuai petunjuk Gomez dan Gomez (2010). Analisis data menggunakan program SAS 9.1.

\section{Hasil dan Pembahasan}

3.1 Suhu Tanah

Suhu tanah selama penelitian berfluktuasi dari pengamatan awal hingga pengamatan terakhir dengan kisaran suhu antara $27,2-31^{\circ} \mathrm{C}$. Hasil sidik ragam (Anova) menunjukkan tidak terjadi pengaruh interaksi antara takaran pupuk kadang sapi dan varietas kedelai terhadap suhu tanah setiap waktu pengamatan.

Data Tabel 1. menunjukkan bahwa pada saat pengamatan $25 \mathrm{HST}$, suhu tanah petak yang diberikan pupuk kandang dengan takaran $40 \mathrm{t} / \mathrm{ha}$ cenderung lebih tinggi tetapi tidak berbeda nyata dengan suhu tanah pada petak yang diberikan pupuk kandang dengan takaran 30 t/ha dan yang tidak diberikan pupuk kandang sapi. Pada pengamatan 50 HST juga belum terjadi pengaruh utama takaran pupuk kandang sapi tetapi suhu tanah pada petak yang tidak diberikan pupuk kandang sapi yang lebih tinggi dan pada pengamatan 75 HST takaran pupuk kandang berpengaruh secara nyata terhadap suhu tanah dimana petak yang tidak diberikan pupuk kandang memiliki suhu tanah yang paling tinggi dan berbeda nyata dengan suhu tanah petak yang diberikan pupuk kandang dengan takaran 40 t/ha maupun 30 t/ha.

Pengaruh utama varietas kedelai tidak terjadi secara nyata terhadap suhu tanah setiap waktu pengamatan. Suhu tanah pada petak dimana jagung ditumpangsarikan dengan kedelai varietas Lokal pada pengamatan 25 HST dan 50 HST cenderung lebih tinggi tetapi pada saat pengamatan terakhir, suhu tanah pada petak dimana jagung ditumpangsarikan dengan kedelai varietas Willis cenderung lebih tinggi sedangkan suhu tanah pada petak dimana jagung ditumpangsarikan dengan kedelai varietas Lokal menjadi paling rendah. 
Tabel 1. Suhu Tanah $\left({ }^{\circ} \mathrm{C}\right)$

\begin{tabular}{|c|c|c|c|c|c|}
\hline \multirow{2}{*}{$\begin{array}{c}\text { Waktu } \\
\text { Pengamatan }\end{array}$} & \multirow{2}{*}{$\begin{array}{l}\text { Takaran Pupuk } \\
\text { Kandang Sapi }\end{array}$} & \multicolumn{3}{|c|}{ Varietas Kedelai } & \multirow{2}{*}{ Rerata } \\
\hline & & Davros & Willis & Lokal & \\
\hline \multirow{4}{*}{25 HST } & $0 \mathrm{t} / \mathrm{ha}$ & $28,8 \mathrm{a}$ & $29,2 \mathrm{a}$ & $29,9 \mathrm{a}$ & $29,3 \mathrm{a}$ \\
\hline & $30 \mathrm{t} / \mathrm{ha}$ & $29,7 \mathrm{a}$ & $28,8 \mathrm{a}$ & $29,5 \mathrm{a}$ & $29,3 \mathrm{a}$ \\
\hline & $40 \mathrm{t} / \mathrm{ha}$ & $29,3 \mathrm{a}$ & $30,3 \mathrm{a}$ & $29,6 \mathrm{a}$ & $29,7 \mathrm{a}$ \\
\hline & Rerata & $29,2 \mathrm{a}$ & $29,4 \mathrm{a}$ & $29,6 \mathrm{a}$ & $(-)$ \\
\hline \multirow{4}{*}{$50 \mathrm{HST}$} & $0 \mathrm{t} / \mathrm{ha}$ & $28,3 \mathrm{a}$ & $27,9 \mathrm{a}$ & $28,8 \mathrm{a}$ & $28,3 \mathrm{a}$ \\
\hline & $30 \mathrm{t} / \mathrm{ha}$ & $27,2 \mathrm{a}$ & $27,4 \mathrm{a}$ & $28,4 \mathrm{a}$ & $27,7 \mathrm{a}$ \\
\hline & $40 \mathrm{t} / \mathrm{ha}$ & $27,4 \mathrm{a}$ & $27,4 \mathrm{a}$ & $28,3 \mathrm{a}$ & $27,7 \mathrm{a}$ \\
\hline & Rerata & $27,6 \mathrm{a}$ & $27,6 \mathrm{a}$ & $28,5 \mathrm{a}$ & $(-)$ \\
\hline \multirow{4}{*}{75 HST } & $0 \mathrm{t} / \mathrm{ha}$ & $30,9 \mathrm{a}$ & $31,0 \mathrm{a}$ & $29,1 \mathrm{a}$ & $30,3 \mathrm{a}$ \\
\hline & $30 \mathrm{t} / \mathrm{ha}$ & $28,5 \mathrm{a}$ & $29,1 \mathrm{a}$ & $28,7 \mathrm{a}$ & $28,8 \mathrm{~b}$ \\
\hline & $40 \mathrm{t} / \mathrm{ha}$ & 29,0 a & 29,3 a & $29,4 \mathrm{a}$ & $29,2 \mathrm{~b}$ \\
\hline & Rerata & $29,5 \mathrm{a}$ & $29,8 \mathrm{a}$ & $29,1 \mathrm{a}$ & $(-)$ \\
\hline
\end{tabular}

Keterangan: Angka yang diikuti dengan huruf yang sama pada kolom atau baris yang sama tidak berbeda nyata menurut uji DMRT@ @\%. (-): Tidak terjadi interaksi antara faktor

\subsection{Kadar Lengas Tanah}

Kadar lengas tanah semakin menurun dari pengamatan awal hingga pengamatan selanjutnya. Hasil sidik ragam (Anova) menunjukkan tidak terjadi pengaruh interaksi antara takaran pupuk kadang sapi dan varietas kedelai terhadap kadar lengas tanah setiap waktu pengamatan.

Pengaruh utama takaran pupuk kandang sapi tidak terjadi secara nyata terhadap kadar lengas tanah waktu pengamatan 25 HST, tetapi data Tabel 2. menunjukkan kadar lengas tanah pada petak yang diberikan pupuk kandang dengan takaran $40 \mathrm{t} / \mathrm{ha}$ cenderung lebih tinggi, selanjutnya pada pengamatan 50 HST kadar lengas tanah pada petak yang diberikan pupuk kandang dengan takaran 40 t/ha tetap paling tinggi dan berbeda secara nyata dengan level perlakuan yang lainnya. Pada pengamatan 75 HST kadar lengas tanah pada petak yang diberikan pupuk kandang dengan takaran 30 t/ha cenderung lebih tinggi walaupun tidak berbeda nyata dengan level perlakuan lainnya..

Pengaruh utama varietas kedelai tidak terjadi secara nyata terhadap kadar lengas tanah setiap waktu pengamatan. Kadar lengas tanah pada petak dimana jagung ditumpangsarikan dengan kedelai varietas Willis cenderung lebih tinggi saat pengamatan 25 HST dan 75 HST sedangkan saat 50 HST kadar lengas yang lebih tinggi terdapat pada petak dimana jagung ditumpangsarikan dengan kedelai varietas Davros.

Tabel 2. Kadar Lengas Tanah (\%)

\begin{tabular}{|c|c|c|c|c|c|}
\hline \multirow{2}{*}{$\begin{array}{c}\text { Waktu } \\
\text { Pengamatan }\end{array}$} & \multirow{2}{*}{$\begin{array}{l}\text { Takaran Pupuk } \\
\text { Kandang Sapi }\end{array}$} & \multicolumn{3}{|c|}{ Varietas Kedelai } & \multirow{2}{*}{ Rerata } \\
\hline & & Davros & Willis & Lokal & \\
\hline \multirow{4}{*}{$25 \mathrm{HST}$} & $0 \mathrm{t} / \mathrm{hal}$ & $27,2 \mathrm{a}$ & $28,4 \mathrm{a}$ & $26,9 \mathrm{a}$ & $27,5 \mathrm{a}$ \\
\hline & $30 \mathrm{t} / \mathrm{ha}$ & $24,9 \mathrm{a}$ & $27,7 \mathrm{a}$ & $25,9 \mathrm{a}$ & $26,2 \mathrm{a}$ \\
\hline & $40 \mathrm{t} / \mathrm{ha}$ & $28,5 \mathrm{a}$ & $27,9 \mathrm{a}$ & $27,1 \mathrm{a}$ & $27,8 \mathrm{a}$ \\
\hline & Rerata & $26,9 \mathrm{a}$ & $28,0 \mathrm{a}$ & $26,6 \mathrm{a}$ & $(-)$ \\
\hline \multirow{4}{*}{$50 \mathrm{HST}$} & $0 \mathrm{t} / \mathrm{ha}$ & $15,7 \mathrm{a}$ & $18,0 \mathrm{a}$ & $12,5 \mathrm{a}$ & $15,4 \mathrm{~b}$ \\
\hline & $30 \mathrm{t} / \mathrm{ha}$ & $14,9 \mathrm{a}$ & $17,3 \mathrm{a}$ & $14,6 \mathrm{a}$ & $15,6 \mathrm{~b}$ \\
\hline & $40 \mathrm{t} / \mathrm{ha}$ & $23,7 \mathrm{a}$ & $16,9 \mathrm{a}$ & $19,2 \mathrm{a}$ & $20,0 \mathrm{a}$ \\
\hline & Rerata & $18,1 \mathrm{a}$ & $17,4 \mathrm{a}$ & $15,4 \mathrm{a}$ & $(-)$ \\
\hline \multirow{4}{*}{75 HST } & $0 \mathrm{t} / \mathrm{ha}$ & $12,5 \mathrm{a}$ & $14,3 \mathrm{a}$ & $11,8 \mathrm{a}$ & $12,9 \mathrm{a}$ \\
\hline & $30 \mathrm{t} / \mathrm{ha}$ & $14,1 \mathrm{a}$ & $12,8 \mathrm{a}$ & $16,0 \mathrm{a}$ & $14,3 \mathrm{a}$ \\
\hline & $40 \mathrm{t} / \mathrm{ha}$ & $13,9 \mathrm{a}$ & $14,6 \mathrm{a}$ & $12,2 \mathrm{a}$ & $13,6 \mathrm{a}$ \\
\hline & Rerata & $13,5 \mathrm{a}$ & $13,9 \mathrm{a}$ & $13,3 \mathrm{a}$ & $(-)$ \\
\hline
\end{tabular}

3.3 Berat Volume Tanah

Hasil sidik ragam (Anova) menunjukkan tidak terjadi pengaruh interaksi antara takaran pupuk kadang sapi dan varietas kedelai terhadap berat volume tanah setiap waktu pengamatan. Pengaruh utama baik takaran pupuk kandang sapi maupun varietas kedelai juga tidak terjadi secara nyata terhadap berat volume tanah setiap waktu pengamatan tetapi data pada Tabel 3. menunjukkan bahwa berat volume tanah pada petak yang diberikan pupuk kandang dengan takaran 40 t/ha selalu cenderung lebih tinggi.

Tabel 3. Berat Volume Tanah $\left(\mathrm{g} / \mathrm{cm}^{3}\right)$

\begin{tabular}{|c|c|c|c|c|c|}
\hline \multirow{2}{*}{$\begin{array}{c}\text { Waktu } \\
\text { Pengamatan }\end{array}$} & \multirow{2}{*}{$\begin{array}{l}\text { Takaran Pupuk } \\
\text { Kandang Sapi }\end{array}$} & \multicolumn{3}{|c|}{ Varietas Kedelai } & \multirow{2}{*}{ Rerata } \\
\hline & & Davros & Willis & Lokal & \\
\hline \multirow{4}{*}{$25 \mathrm{HST}$} & $0 \mathrm{t} / \mathrm{ha}$ & $1,43 \mathrm{a}$ & $1,46 \mathrm{a}$ & $1,41 \mathrm{a}$ & $1,43 \mathrm{a}$ \\
\hline & $30 \mathrm{t} / \mathrm{ha}$ & $1,37 \mathrm{a}$ & $1,43 \mathrm{a}$ & $1,40 \mathrm{a}$ & $1,40 \mathrm{a}$ \\
\hline & $40 \mathrm{t} / \mathrm{ha}$ & $1,46 \mathrm{a}$ & $1,43 \mathrm{a}$ & $1,42 \mathrm{a}$ & $1,44 \mathrm{a}$ \\
\hline & Rerata & $1,42 \mathrm{a}$ & $1,44 \mathrm{a}$ & $1,41 \mathrm{a}$ & $(-)$ \\
\hline \multirow{4}{*}{$50 \mathrm{HST}$} & $0 \mathrm{t} / \mathrm{ha}$ & $1,38 \mathrm{a}$ & $1,54 \mathrm{a}$ & $1,49 \mathrm{a}$ & $1,47 \mathrm{a}$ \\
\hline & $30 \mathrm{t} / \mathrm{ha}$ & $1,48 \mathrm{a}$ & $1,51 \mathrm{a}$ & $1,56 \mathrm{a}$ & $1,52 \mathrm{a}$ \\
\hline & $40 \mathrm{t} / \mathrm{ha}$ & $1,55 \mathrm{a}$ & $1,49 \mathrm{a}$ & $1,60 \mathrm{a}$ & $1,55 \mathrm{a}$ \\
\hline & Rerata & $1,47 \mathrm{a}$ & $1,51 \mathrm{a}$ & $1,55 \mathrm{a}$ & $(-)$ \\
\hline \multirow{4}{*}{75 HST } & $0 \mathrm{t} / \mathrm{ha}$ & $1,78 \mathrm{a}$ & $2,09 \mathrm{a}$ & $1,71 \mathrm{a}$ & $1,86 \mathrm{a}$ \\
\hline & $30 \mathrm{t} / \mathrm{ha}$ & $1,88 \mathrm{a}$ & $2,03 \mathrm{a}$ & $1,82 \mathrm{a}$ & $1,91 \mathrm{a}$ \\
\hline & $40 \mathrm{t} / \mathrm{ha}$ & $2,24 \mathrm{a}$ & $2,16 \mathrm{a}$ & $2,09 \mathrm{a}$ & $2,16 \mathrm{a}$ \\
\hline & Rerata & $1,97 \mathrm{a}$ & $2,09 \mathrm{a}$ & $1,87 \mathrm{a}$ & $(-)$ \\
\hline
\end{tabular}

Berat volume tanah pada petak dimana jagung ditumpangsarikan dengan kedelai varietas Willis cenderung lebih tinggi saat pengamatan 25 HST dan 75 HST sedangkan saat 50 HST berat volume tanah yang lebih tinggi terdapat pada petak dimana jagung ditumpangsarikan dengan kedelai varietas Lokal. 3.4 Tinggi Tanaman

Tanaman terus bertambah tinggi selama penelitian. Hasil sidik ragam (Anova) menunjukkan tidak terjadi pengaruh interaksi antara takaran pupuk kadang sapi dan varietas kedelai terhadap tinggi tanaman setiap waktu pengamatan.
Pengaruh utama baik takaran pupuk kandang sapi maupun varietas kedelai juga tidak terjadi secara nyata terhadap tinggi tanaman setiap waktu pengamatan tetapi data pada Tabel 4. menunjukkan bahwa jagung yang diberikan pupuk kandang dengan takaran 40 t/ha selalu cenderung lebih tinggi pada setiap waktu pengamatan sedangkan jagung yang tidak diberikan pupuk kandang selalu lebih pendek. Demikian pula dengan jagung yang ditumpangsarikan dengan kedelai varietas Lokal selalu cenderung lebih tinggi pada setiap waktu pengamatan sedangkan jagung yang ditumpangsarikan dengan kedelai varietas Davros selalu lebih pendek. 
Tabel 4. Tinggi Tanaman Jagung (cm)

\begin{tabular}{|c|c|c|c|c|c|}
\hline \multirow{2}{*}{$\begin{array}{c}\text { Waktu } \\
\text { Pengamatan }\end{array}$} & \multirow{2}{*}{$\begin{array}{l}\text { Takaran Pupuk } \\
\text { Kandang Sapi }\end{array}$} & \multicolumn{3}{|c|}{ Varietas Kedelai } & \multirow{2}{*}{ Rerata } \\
\hline & & Davros & Willis & Lokal & \\
\hline \multirow{4}{*}{$25 \mathrm{HST}$} & 0 t/ha & $89,3 \mathrm{a}$ & $106,4 \mathrm{a}$ & $118,5 \mathrm{a}$ & $104,7 \mathrm{a}$ \\
\hline & $30 \mathrm{t} / \mathrm{ha}$ & $103,1 \mathrm{a}$ & $112,3 \mathrm{a}$ & $127,6 \mathrm{a}$ & $114,3 \mathrm{a}$ \\
\hline & $40 \mathrm{t} / \mathrm{ha}$ & $126,3 \mathrm{a}$ & $132,5 \mathrm{a}$ & $132,3 \mathrm{a}$ & $130,4 \mathrm{a}$ \\
\hline & Rerata & $106,2 \mathrm{a}$ & $117,1 \mathrm{a}$ & $126,2 \mathrm{a}$ & $(-)$ \\
\hline \multirow{4}{*}{$50 \mathrm{HST}$} & $0 \mathrm{t} / \mathrm{ha}$ & $100,6 \mathrm{a}$ & $118,8 \mathrm{a}$ & $130,6 \mathrm{a}$ & $116,7 \mathrm{a}$ \\
\hline & $30 \mathrm{t} / \mathrm{ha}$ & $115,0 \mathrm{a}$ & $123,8 \mathrm{a}$ & $137,9 \mathrm{a}$ & $125,6 \mathrm{a}$ \\
\hline & $40 \mathrm{t} / \mathrm{ha}$ & $139,6 \mathrm{a}$ & $143,8 \mathrm{a}$ & $142,9 \mathrm{a}$ & $142,1 \mathrm{a}$ \\
\hline & Rerata & $118,4 \mathrm{a}$ & $128,8 \mathrm{a}$ & $137,1 \mathrm{a}$ & $(-)$ \\
\hline \multirow{4}{*}{$75 \mathrm{HST}$} & $0 \mathrm{t} / \mathrm{ha}$ & $104,5 \mathrm{a}$ & $121,3 \mathrm{a}$ & $133,2 \mathrm{a}$ & $119,7 \mathrm{a}$ \\
\hline & $30 \mathrm{t} / \mathrm{ha}$ & $118,5 \mathrm{a}$ & $126,3 \mathrm{a}$ & $141,1 \mathrm{a}$ & $128,6 \mathrm{a}$ \\
\hline & $40 \mathrm{t} / \mathrm{ha}$ & $142,9 \mathrm{a}$ & $146,9 \mathrm{a}$ & $146,7 \mathrm{a}$ & $145,5 \mathrm{a}$ \\
\hline & Rerata & $122,0 \mathrm{a}$ & $131,5 \mathrm{a}$ & $140,3 \mathrm{a}$ & $(-)$ \\
\hline
\end{tabular}

Angka yang diikuti dengan huruf yang sama pada

3.5 Diameter Batang

Batang tanaman terus bertambah besar selama penelitian. Hasil sidik ragam (Anova) menunjukkan tidak terjadi pengaruh interaksi antara takaran pupuk kadang sapi dan varietas kedelai terhadap diameter batang setiap waktu pengamatan.

Pengaruh utama takaran pupuk kandang sapi terjadi secara nyata terhadap diameter batang pada pengamatan 25 HST dimana batang jagung yang diberikan pupuk kandang dengan takaran $40 \mathrm{t} / \mathrm{ha}$ paling besar dan berbeda nyata dengan batang jagung yang tidak diberikan pupuk kandang. Pada pengamatan selanjutnya takaran pupuk kandang sapi tidak berpengaruh secara nyata terhadap diameter batang tetapi data pada Tabel 5. menunjukkan bahwa batang jagung yang diberikan pupuk kandang dengan takaran $40 \mathrm{t} / \mathrm{ha}$ selalu cenderung lebih besar pada setiap waktu pengamatan sedangkan batang jagung yang tidak diberikan pupuk kandang selalu lebih kecil.

Pengaruh utama varietas kedelai tidak terjadi secara nyata terhadap diameter batang setiap waktu pengamatan. Batang jagung yang ditumpangsarikan dengan kedelai varietas Lokal selalu cenderung lebih besar pada setiap waktu pengamatan sedangkan jagung yang ditumpangsarikan dengan kedelai varietas Davros selalu lebih kecil.

Tabel 5. Diameter Batang Jagung (mm)

\begin{tabular}{|c|c|c|c|c|c|}
\hline \multirow{2}{*}{$\begin{array}{c}\text { Waktu } \\
\text { Pengamatan }\end{array}$} & \multirow{2}{*}{$\begin{array}{l}\text { Takaran Pupuk } \\
\text { Kandang Sapi }\end{array}$} & \multicolumn{3}{|c|}{ Varietas Kedelai } & \multirow{2}{*}{ Rerata } \\
\hline & & Davros & Willis & Lokal & \\
\hline \multirow{4}{*}{25 HST } & $0 \mathrm{t} / \mathrm{ha}$ & $1,17 \mathrm{a}$ & $1,26 \mathrm{a}$ & $1,28 \mathrm{a}$ & $1,24 \mathrm{~b}$ \\
\hline & $30 \mathrm{t} / \mathrm{ha}$ & $1,41 \mathrm{a}$ & $1,23 \mathrm{a}$ & $1,38 \mathrm{a}$ & $1,34 \mathrm{a}$ \\
\hline & $40 \mathrm{t} / \mathrm{ha}$ & $1,32 \mathrm{a}$ & $1,50 \mathrm{a}$ & $1,46 \mathrm{a}$ & $1,42 \mathrm{a}$ \\
\hline & Rerata & $1,30 \mathrm{a}$ & $1,33 \mathrm{a}$ & $1,37 \mathrm{a}$ & $(-)$ \\
\hline \multirow{4}{*}{$50 \mathrm{HST}$} & $0 \mathrm{t} / \mathrm{ha}$ & $1,31 \mathrm{a}$ & $1,37 \mathrm{a}$ & $1,41 \mathrm{a}$ & $1,37 \mathrm{a}$ \\
\hline & $30 \mathrm{t} / \mathrm{ha}$ & $1,54 \mathrm{a}$ & $1,41 \mathrm{a}$ & $1,54 \mathrm{a}$ & $1,50 \mathrm{a}$ \\
\hline & $40 \mathrm{t} / \mathrm{ha}$ & $1,51 \mathrm{a}$ & $1,65 \mathrm{a}$ & $1,69 \mathrm{a}$ & $1,62 \mathrm{a}$ \\
\hline & Rerata & $1,45 \mathrm{a}$ & $1,48 \mathrm{a}$ & $1,55 \mathrm{a}$ & \\
\hline \multirow{4}{*}{75 HST } & $0 \mathrm{t} / \mathrm{ha}$ & $1,17 \mathrm{a}$ & $1,47 \mathrm{a}$ & $1,45 \mathrm{a}$ & $1,36 \mathrm{a}$ \\
\hline & $30 \mathrm{t} / \mathrm{ha}$ & $1,57 \mathrm{a}$ & $1,51 \mathrm{a}$ & $1,58 \mathrm{a}$ & $1,55 \mathrm{a}$ \\
\hline & $40 \mathrm{t} / \mathrm{ha}$ & $1,54 \mathrm{a}$ & $1,68 \mathrm{a}$ & $1,71 \mathrm{a}$ & $1,65 \mathrm{a}$ \\
\hline & Rerata & $1,43 \mathrm{a}$ & $1,55 \mathrm{a}$ & $1,58 \mathrm{a}$ & $(-)$ \\
\hline
\end{tabular}

@ $5 \%$. (-): Tidak terjadi interaksi antara faktor

3.6 Luas Daun

Hasil sidik ragam (Anova) menunjukkan tidak terjadi pengaruh interaksi antara takaran pupuk kadang sapi dan varietas kedelai terhadap luas daun. Pengaruh utama baik takaran pupuk kandang sapi maupun varietas kedelai juga tidak terjadi secara nyata terhadap luas daun.

Tabel 6. Luas Daun $\left(\mathrm{cm}^{2}\right)$

\begin{tabular}{ccccc}
\hline Takaran Pupuk Kandang & \multicolumn{3}{c}{ Varietas Kedelai } & \multirow{2}{*}{ Rerata } \\
\cline { 2 - 4 } Sapi & Davros & Willis & Lokal & $1244,8 \mathrm{a}$ \\
$30 \mathrm{t} / \mathrm{ha}$ & $1004,1 \mathrm{a}$ & $1048,1 \mathrm{a}$ & $1682,2 \mathrm{a}$ & $1631,0 \mathrm{a}$ \\
$40 \mathrm{t} / \mathrm{ha}$ & $1688,9 \mathrm{a}$ & $1849,7 \mathrm{a}$ & $1354,4 \mathrm{a}$ & $1709,8 \mathrm{a}$ \\
\hline Rerata & $1852,1 \mathrm{a}$ & $1358,2 \mathrm{a}$ & $1919,2 \mathrm{a}$ & $(-)$ \\
\hline Keterangan: & Angka yang diikuti dengan huruf yang sama pada kolom atau baris yang sama tidak berbeda nyata menurut uji DMRT \\
& @ $5 \% .(-)$ : Tidak terjadi interaksi antara faktor &
\end{tabular}

3.7 Jumlah Bulir Per TanamanJagung

Hasil sidik ragam (Anova) menunjukkan tidak terjadi pengaruh interaksi antara takaran pupuk kadang sapi dan varietas kedelai terhadap jumlah bulir per
Data pada Tabel 6. menunjukkan bahwa permukaan daun jagung yang diberikan pupuk kandang dengan takaran 40 t/ha cenderung lebih luas sedangkan permukaan daun jagung yang tidak diberikan pupuk kandang paling sempit. Demikian pula dengan permukaan daun jagung yang ditumpangsarikan dengan kedelai varietas Lokal cenderung lebih luas sedangkan permukaan daun jagung yang ditumpangsarikan dengan kedelai varietas Willis paling sempit.

Tabel 7. Jumlah Bulir Per Tanaman

\begin{tabular}{ccccc}
\hline Takaran Pupuk Kandang & \multicolumn{3}{c}{ Varietas Kedelai } & \multirow{2}{*}{ Rerata } \\
\cline { 2 - 4 } Sapi & Davros & Willis & Lokal & $1,2 \mathrm{a}$ \\
$30 \mathrm{t} / \mathrm{ha}$ & $1,4 \mathrm{a}$ & $1,4 \mathrm{a}$ & $0,9 \mathrm{a}$ & $1,4 \mathrm{a}$ \\
$40 \mathrm{t} / \mathrm{ha}$ & $1,5 \mathrm{a}$ & $1,4 \mathrm{a}$ & $1,4 \mathrm{a}$ & $1,8 \mathrm{a}$ \\
\hline Rerata & $1,6 \mathrm{a}$ & $1,7 \mathrm{a}$ & $1,9 \mathrm{a}$ & $(-)$ \\
\hline Keterangan: & $1,5 \mathrm{a}$ & $1,5 \mathrm{a}$ & $1,4 \mathrm{a}$ & \\
\hline & Angka yang diikuti dengan huruf yang sama pada kolom atau baris yang sama tidak berbeda nyata menurut uji DMRT
\end{tabular}

$$
\text { @ 5\%.(-): Tidak terjadi interaksi antara faktor }
$$

Data pada Tabel 7. menunjukkan bahwa jagung yang diberikan pupuk kandang dengan takaran 40 t/ha menghasilkan jumlah bulir per tanaman yang cenderung lebih banyak sedangkan jagung yang tidak diberikan pupuk kandang tanaman. Pengaruh utama baik takaran pupuk kandang sapi maupun varietas kedelai juga tidak terjadi secara nyata terhadap terhadap jumlah bulir per tanaman. 
tanaman jagung yang ditumpangsarikan dengan kedelai varietas Lokal paling sedikit.

3.8 Jumlah Baris Per Bulir Jagung

Hasil sidik ragam (Anova) menunjukkan tidak terjadi pengaruh interaksi antara takaran pupuk kadang sapi dan varietas kedelai terhadap jumlah baris per bulir. Pengaruh utama takaran pupuk kandang sapi tidak terjadi secara nyata terhadap jumlah baris per bulir. Data pada Tabel 8. menunjukkan bahwa jagung yang diberikan pupuk kandang dengan takaran 30 t/ha menghasilkan jumlah baris per bulir yang cenderung lebih banyak sedangkan jagung yang diberikan pupuk kandang dengan takaran 40 t/ha menghasilkan jumlah baris per bulir yang paling sedikit.

Jumlah baris per bulir secara nyata dipengaruhi oleh variets kedelai dimana jumlah baris per bulir jagung yang ditumpangsarikan dengan kedelai varietas Lokal paling banyak dan berbeda secara nyata dengan jumlah baris per bulir jagung yang ditumpangsarikan dengan kedelai varietas Willis maupun Davros.

Tabel 8. Jumlah Baris Per Bulir

\begin{tabular}{ccccc}
\hline \multirow{2}{*}{$\begin{array}{c}\text { Takaran Pupuk Kandang } \\
\text { Sapi }\end{array}$} & \multicolumn{3}{c}{ Varietas Kedelai } & \multirow{2}{*}{ Rerata } \\
\cline { 2 - 4 } 0 & Davros & Willis & Lokal & \\
\hline $0 \mathrm{t} / \mathrm{ha}$ & $5,3 \mathrm{a}$ & $5,9 \mathrm{a}$ & $9,2 \mathrm{a}$ & $6,8 \mathrm{a}$ \\
$30 \mathrm{t} / \mathrm{ha}$ & $6,5 \mathrm{a}$ & $7,4 \mathrm{a}$ & $6,8 \mathrm{a}$ & $6,9 \mathrm{a}$ \\
$40 \mathrm{t} / \mathrm{ha}$ & $6,4 \mathrm{a}$ & $5,9 \mathrm{a}$ & $5,9 \mathrm{a}$ & $6,0 \mathrm{a}$ \\
\hline Rerata & $6,1 \mathrm{~b}$ & $6,4 \mathrm{~b}$ & $7,3 \mathrm{a}$ & $(-)$ \\
\hline Keterangan: & Angka yang diikuti dengan huruf yang sama pada kolom atau baris yang sama tidak berbeda nyata menurut uji DMRT \\
& @ 5\%. (-) : Tidak terjadi interaksi antara faktor
\end{tabular}

3.9 Jumlah Biji Per Baris Jagung

Hasil sidik ragam (Anova) menunjukkan tidak terjadi pengaruh interaksi antara takaran pupuk kadang sapi dan varietas kedelai terhadapjumlah biji per baris. Pengaruh utama takaran pupuk kandang sapi terjadi secara nyata terhadap jumlah biji per baris dimana jagung yang diberikan pupuk kandang dengan takaran 40 t/ha menghasilkan jumlah biji per baris yang paling banyak dan berbeda nyata dengan jumlah biji per baris jagung yang tidak diberikan pupuk kandang sapi maupun jagung yang diberikan pupuk kandang dengan takaran 30 t/ha yang menghasilkan jumlah biji per baris yang paling sedikit.

Jumlah biji per baris secara nyata dipengaruhi oleh variets kedelai dimana jumlah biji per baris jagung yang ditumpangsarikan dengan kedelai varietas Davros paling banyak dan berbeda secara nyata dengan jumlah biji per baris jagung yang ditumpangsarikan dengan kedelai varietas Lokal maupun Willis.

Tabel 9. Jumlah Biji Per Baris

\begin{tabular}{ccccc}
\hline Takaran Pupuk Kandang & \multicolumn{3}{c}{ Varietas Kedelai } & \multirow{2}{*}{ Rerata } \\
\cline { 2 - 4 } Sapi & Davros & Willis & Lokal & \\
\hline $0 \mathrm{t} / \mathrm{ha}$ & $30,0 \mathrm{a}$ & $20,1 \mathrm{a}$ & $13,7 \mathrm{a}$ & $21,3 \mathrm{~b}$ \\
$30 \mathrm{t} / \mathrm{ha}$ & $21,6 \mathrm{a}$ & $17,5 \mathrm{a}$ & $20,9 \mathrm{a}$ & $20,0 \mathrm{~b}$ \\
$40 \mathrm{t} / \mathrm{ha}$ & $29,8 \mathrm{a}$ & $22,3 \mathrm{a}$ & $35,2 \mathrm{a}$ & $29,1 \mathrm{a}$ \\
\hline Rerata & $27,1 \mathrm{a}$ & $20,0 \mathrm{~b}$ & $23,3 \mathrm{~b}$ & $(-)$ \\
\hline \multicolumn{2}{c}{ Keterangan: } & Angka yang diikuti dengan huruf yang sama pada kolom atau baris yang sama tidak berbeda nyata menurut uji DMRT \\
& @ 5\%.(-): Tidak terjadi interaksi antara faktor
\end{tabular}

\subsection{Berat Kering Biji Per Tanaman}

Hasil sidik ragam (Anova) menunjukkan tidak terjadi pengaruh interaksi antara takaran pupuk kadang sapi dan varietas kedelai terhadap berat kering biji per tanaman. Pengaruh utama baik takaran pupuk kandang sapi maupun varietas kedelai juga tidak terjadi secara nyata terhadap berat kering biji per tanaman.

Data pada Tabel 10. menunjukkan bahwa jagung yang diberikan pupuk kandang dengan takaran 40 t/ha menghasilkan berat kering biji per tanaman yang cenderung lebih berat sedangkan jagung yang tidak diberikan pupuk kandang menghasilkan berat kering biji per tanaman yang paling ringan. Demikian pula dengan berat kering biji per tanaman jagung yang ditumpangsarikan dengan kedelai varietas Lokal cenderung lebih berat sedangkan berat kering biji per tanaman jagung yang ditumpangsarikan dengan kedelai varietas Davros paling ringan.

Tabel 10. Berat Kering Biji Per Tanaman (g)

\begin{tabular}{ccccc} 
Tabel 10. Berat Kering Biji Per Tanaman $(\mathrm{g})$ & \multirow{3}{*}{ Rerata } \\
\cline { 2 - 4 } Takaran Pupuk Kandang & Davros & Willis & Lokal & \\
\cline { 2 - 4 } Sapi & $155,2 \mathrm{a}$ & $121,9 \mathrm{a}$ & $118,6 \mathrm{a}$ & $131,9 \mathrm{a}$ \\
$0 \mathrm{t} / \mathrm{ha}$ & $254,3 \mathrm{a}$ & $213,5 \mathrm{a}$ & $245,7 \mathrm{a}$ & $237,9 \mathrm{a}$ \\
$30 \mathrm{t} / \mathrm{ha}$ & $441,1 \mathrm{a}$ & $246,1 \mathrm{a}$ & $592,3 \mathrm{a}$ & $426,5 \mathrm{a}$ \\
\hline $0 \mathrm{t} / \mathrm{ha}$ & $283,5 \mathrm{a}$ & $193,8 \mathrm{a}$ & $318,9 \mathrm{a}$ & $(-)$ \\
\hline Rerata & &
\end{tabular}

Keterangan: $\quad$ Angka yang diikuti dengan huruf yang sama pada kolom atau baris yang sama tidak berbeda nyata menurut uji DMRT @ $5 \% .(-)$ : Tidak terjadi interaksi antara faktor

\subsection{Berat Kering 100 Biji}

Hasil sidik ragam (Anova) menunjukkan tidak terjadi pengaruh interaksi antara takaran pupuk kadang sapi dan varietas kedelai terhadap berat kering 100 biji. Takaran pupuk kandang sapi secara nyata berpengaruh terhadap berat kering 100 biji dimana jagung yang diberikan pupuk kandang dengan takaran 40 t/ha menghasilkan berat kering 100 biji yang paling berat dan berbeda nyata dengan berat kering 100 biji jagung yang diberikan pupuk kandang dengan takaran 30 t/ha maupun jagung yang tidak diberikan pupuk kandang yang menghasilkan berat kering 100 biji yang paling ringan.

Pengaruh utama varietas kedelai tidak terjadi secara nyata terhadap berat kering 100 biji tetapi data pada Tabel 11. Menunjukkan berat kering 100 biji jagung yang ditumpangsarikan dengan kedelai varietas Lokal cenderung lebih berat sedangkan berat kering 100 biji jagung yang ditumpangsarikan dengan kedelai varietas Davros paling ringan.

Tabel 11. Berat Kering 100 Biji (g)

\begin{tabular}{ccccc}
\hline Takaran Pupuk Kandang & \multicolumn{3}{c}{ Varietas Kedelai } & Rerata \\
\cline { 2 - 4 } Sapi & Davros & Willis & Lokal & \\
\hline $0 \mathrm{t} / \mathrm{ha}$ & $20,8 \mathrm{a}$ & $22,3 \mathrm{a}$ & $22,8 \mathrm{a}$ & $24,3 \mathrm{~b}$ \\
$30 \mathrm{t} / \mathrm{ha}$ & $24,1 \mathrm{a}$ & $25,8 \mathrm{a}$ & $24,6 \mathrm{a}$ & $24,8 \mathrm{~b}$ \\
$40 \mathrm{t} / \mathrm{ha}$ & $29,3 \mathrm{a}$ & $28,9 \mathrm{a}$ & $30,9 \mathrm{a}$ & $29,7 \mathrm{a}$ \\
\hline Rerata & $24,7 \mathrm{a}$ & $25,7 \mathrm{a}$ & $26,4 \mathrm{a}$ & \\
\hline
\end{tabular}

Keterangan: $\quad$ Angka yang diikuti dengan huruf yang sama pada kolom atau baris yang sama tidak berbeda nyata menurut uji DMRT (a) $5 \%$. (-): Tidak terjadi interaksi antara faktor

3.12 Berat Kering Biji Per Petak

Hasil sidik ragam (Anova) menunjukkan tidak terjadi pengaruh interaksi antara takaran pupuk kadang sapi dan varietas kedelai terhadapberat kering biji per petak.

Pengaruh utama takaran pupuk kandang sapi terjadi secara nyata terhadap berat kering biji per petak dimana jagung yang diberikan pupuk kandang dengan takaran 40 t/ha menghasilkan berat kering biji per petak yang paling berat dan berbeda nyata dengan berat kering biji per petak jagung yang diberikan pupuk kandang dengan takaran 30 t/ha maupun jagung yang tidak diberikan pupuk kandang sapi yang menghasilkan berat kering biji per petak yang paling ringan.

Berat kering biji per petak secara nyata dipengaruhi oleh variets kedelai dimana berat kering biji per petak jagung yang ditumpangsarikan dengan kedelai varietas Lokalpaling berat dan berbeda secara nyata dengan berat kering biji per petak jagung yang ditumpangsarikan dengan kedelai varietas Davros maupun Willis. 
Tabel 12. Berat Kering Biji Per Petak (t/ha)

\begin{tabular}{ccccc}
\hline Takaran Pupuk Kandang & \multicolumn{3}{c}{ Varietas Kedelai } & \multirow{2}{*}{ Rerata } \\
\cline { 2 - 4 } Sapi & Davros & Willis & Lokal & $0,2 \mathrm{~b}$ \\
$0 \mathrm{t} / \mathrm{ha}$ & $0,2 \mathrm{a}$ & $0,3 \mathrm{a}$ & $0,2 \mathrm{a}$ & $0,5 \mathrm{~b}$ \\
$30 \mathrm{t} / \mathrm{ha}$ & $0,5 \mathrm{a}$ & $0,4 \mathrm{a}$ & $0,5 \mathrm{a}$ & $1,0 \mathrm{a}$ \\
$40 \mathrm{t} / \mathrm{ha}$ & $0,9 \mathrm{a}$ & $0,7 \mathrm{a}$ & $1,4 \mathrm{a}$ & $(-)$ \\
\hline Rerata & $0,5 \mathrm{~b}$ & $0,5 \mathrm{~b}$ & $0,7 \mathrm{a}$ & \\
\hline Keterangan: Angka yang diikuti dengan huruf yang sama pada kolom atau baris yang sama tidak berbeda nyata menurut uji DMRT &
\end{tabular}

\subsection{Berat Segar Brangkasan}

Hasil sidik ragam (Anova) menunjukkan tidak terjadi pengaruh interaksi antara takaran pupuk kadang sapi dan varietas kedelai terhadap berat segar berangkasan. Pengaruh utama baik takaran pupuk kandang sapi maupun varietas kedelai juga tidak terjadi secara nyata terhadap berat segar berangkasan

Data pada Tabel 13. menunjukkan bahwa jagung yang diberikan pupuk kandang dengan takaran 40 t/ha memiliki berangkasan segar yang cenderung lebih berat sedangkan jagung yang tidak diberikan pupuk kandang memiliki berat segar berangkasan yang paling ringan. Demikian pula dengan berat segar berangkasan jagung yang ditumpangsarikan dengan kedelai varietas Lokal cenderung lebih berat sedangkan berat segar berangkasan jagung yang ditumpangsarikan dengan kedelai varietas Davros paling ringan.

Tabel 13. Berat Segar Berangkasan (t/ha)

\begin{tabular}{ccccc}
\hline Takaran Pupuk Kandang & \multicolumn{3}{c}{ Varietas Kedelai } & \multirow{2}{*}{ Rerata } \\
\cline { 2 - 4 } Sapi & Davros & Willis & Lokal & $1,5 \mathrm{a}$ \\
$0 \mathrm{t} / \mathrm{ha}$ & $1,3 \mathrm{a}$ & $1,6 \mathrm{a}$ & $1,7 \mathrm{a}$ & $1,6 \mathrm{a}$ \\
$30 \mathrm{t} / \mathrm{ha}$ & $1,4 \mathrm{a}$ & $1,5 \mathrm{a}$ & $1,9 \mathrm{a}$ & $2,0 \mathrm{a}$ \\
$40 \mathrm{t} / \mathrm{ha}$ & $1,8 \mathrm{a}$ & $1,9 \mathrm{a}$ & $(2,2 \mathrm{a}$ & $(-)$ \\
\hline Rerata & $1,5 \mathrm{a}$ & $1,7 \mathrm{a}$ & $\mathrm{a}$ & \\
\hline Keterangan: & Angka yang diikuti dengan huruf yang sama pada kolom atau baris yang sama tidak berbeda nyata menurut uji DMRT
\end{tabular}

\subsection{Berat Kering Brangkasan}

Hasil sidik ragam (Anova) menunjukkan tidak terjadi pengaruh interaksi antara takaran pupuk kadang sapi dan varietas kedelai terhadap berat kering berangkasan. Pengaruh utama baik takaran pupuk kandang sapi maupun varietas kedelai juga tidak terjadi secara nyata terhadap berat kering berangkasan.
Data pada Tabel 14. menunjukkan bahwa berangkasan kering jagung pada ketiga level perlakuan takaran pupuk kandang sapi sama berat, sedangkan bera kering berangkasan jagung yang ditumpangsarikan dengan kedelai varietas Lokal cenderung lebih berat sedangkan berat kering berangkasan jagung yang ditumpangsarikan dengan kedelai varietas Davros paling ringan.

Tabel 14. Berat Kering Berangkasan (t/ha)

\begin{tabular}{ccccc}
\hline \multirow{2}{*}{$\begin{array}{c}\text { Takaran Pupuk Kandang } \\
\text { Sapi }\end{array}$} & \multicolumn{3}{c}{ Varietas Kedelai } & \multirow{2}{*}{ Rerata } \\
\cline { 2 - 4 } $0 \mathrm{t} / \mathrm{ha}$ & Davros & Willis & Lokal & \\
$30 \mathrm{t} / \mathrm{ha}$ & $0,5 \mathrm{a}$ & $0,8 \mathrm{a}$ & $0,8 \mathrm{a}$ & $0,8 \mathrm{a}$ \\
$40 \mathrm{t} / \mathrm{ha}$ & $0,7 \mathrm{a}$ & $0,8 \mathrm{a}$ & $1,0 \mathrm{a}$ & $0,8 \mathrm{a}$ \\
\hline Rerata & $0,8 \mathrm{a}$ & $0,7 \mathrm{a}$ & $0,9 \mathrm{a}$ & $0,8 \mathrm{a}$ \\
\hline Keterangan: & $0,7 \mathrm{a}$ & $0,8 \mathrm{a}$ & $1,0 \mathrm{a}$ & $(-)$ \\
\hline & Angka yang diikuti dengan huruf yang sama pada kolom atau baris yang sama tidak berbeda nyata menurut uji DMRT \\
\hline & &
\end{tabular}

\subsection{Indeks Panen}

Hasil sidik ragam (Anova) menunjukkan tidak terjadi pengaruh interaksi antara takaran pupuk kadang sapi dan varietas kedelai terhadap indeks panen. Pengaruh utama takaran pupuk kandang sapi tidak terjadi secara nyata terhadap indeks panen dimana jagung yang diberikan pupuk kandang dengan takaran 40 t/ha memiliki nilai indeks panen yang paling tinggidan berbeda nyata dengan indeks panen dari jagung yang diberikan pupuk kandang dengan takaran $30 \mathrm{t} / \mathrm{ha}$ maupun jagung yang tidak diberikan pupuk kandang yang nilai indeks panen paling rendah.

Varietas kedelai tidak berpengaruh secara nyata terhadap indeks panen jagung. Indeks panen jagung yang ditumpangsarikan dengan kedelai varietas Davros cenderung lebih tinggi sedangkan indeks panen jagung yang ditumpangsarikan dengan kedelai varietas Willis dan Lokal lebih rendah.

Tabel 15. Indeks Panen (\%)

\begin{tabular}{|c|c|c|c|c|}
\hline \multirow{2}{*}{$\begin{array}{c}\text { Takaran Pupuk Kandang } \\
\text { Sapi } \\
\end{array}$} & \multicolumn{3}{|c|}{ Varietas Kedelai } & \multirow[b]{2}{*}{ Rerata } \\
\hline & Davros & Willis & Lokal & \\
\hline $0 \mathrm{t} / \mathrm{ha}$ & $33,9 \mathrm{a}$ & $25,2 \mathrm{a}$ & $19,4 \mathrm{a}$ & $26,2 \mathrm{~b}$ \\
\hline $30 \mathrm{t} / \mathrm{ha}$ & $42,0 \mathrm{a}$ & $34,1 \mathrm{a}$ & $31,6 \mathrm{a}$ & $35,9 \mathrm{~b}$ \\
\hline $40 \mathrm{t} / \mathrm{ha}$ & $54,0 \mathrm{a}$ & $52,8 \mathrm{a}$ & $61,2 \mathrm{a}$ & $56,0 \mathrm{a}$ \\
\hline Rerata & $43,3 \mathrm{a}$ & $37,4 \mathrm{a}$ & $37,4 \mathrm{a}$ & $(-)$ \\
\hline
\end{tabular}

Keterangan: $\quad$ Angka yang diikuti dengan huruf yang sama pada kolom atau baris yang sama tidak berbeda nyata menurut uji DMRT (a) 5\% . (-): Tidak terjadi interaksi antara faktor

\subsection{Pembahasan}

Pemberian pupuk kandang dengan takaran 40 t/ha secara umum merupakan perlakuan terbaik yang terlihat dari beberapa parameter yang diamati dibandingkan perlakuan kontrol dan pemberian pupuk kandang dengan takaran $30 \mathrm{t} / \mathrm{ha}$, seperti tanaman yang lebih tinggi dengan diameter batang yang lebih besar pada setiap waktu pengamatan, permukaan daun yang lebih luas, jumlah bulir per tanaman, jumlah biji per baris, berat 100 biji, berat kering biji per tanaman maupun per petak, berat segar berangkasan dan indeks panen. Hal ini menunjukkan bahwa takaran pupuk kandang sapi $40 \mathrm{t} / \mathrm{ha}$ belum mencapai titik optimum untuk mendapatkan pertumbuhan dan hasil jagung yang lebih baik sehingga masih memungkinkan untuk meningkatkan takaran pupuk kandang sapi dalam budidaya jagung dan kedelai dengan pola tumpangsari.

Tumpangsari jagung dengan kedelai varietas Lokal secara umum memberikan pertumbuhan dan hasil jagung yang lebih baik dibandingkan jika ditumpangsarikan dengan kedelai varietas Davros maupun Willis. Hal ini terlihat dari beberapa parameter yang diamati, seperti tanaman yang lebih tinggi dengan diameter batang yang lebih besar pada setiap waktu pengamatan, permukaan daun yang lebih luas, jumlah baris per bulir, berat 100 biji, berat kering biji per tanaman maupun per petak serta berat berangkasan segar maupun kering

Selain hasil jagung yang lebih baik, pola tumpangsari yang diterapkan juga memberikan pertumbuhan dan hasil yang lebih baik pada kedelai varietas Lokal dibandingkan kedelai varietas Davros maupun Willis. Data pertumbuhan dan hasil tanaman kedelai dapat dilihat pada Tabel 16. Kedelai varietas Loka memiliki pertumbuhan vegetatif yang tidak terlalu dominan dibanding varietas Willis berupa tanaman yang tidak terlalu tinggi dan batang yang tidak terlalu besar dan permukaan daun tanaman yang lebih luas, tetapi pertumbuhan varietas Lokal lebih baik jika dibandingkan dengan varietas Davros.

Sebaliknya pada hasil tanaman, kedelai varietas lokal memiliki hasil yan lebih baik berupa biji kering per petak yang lebih berat karena walaupun warietas ini menghasilkan setiap biji yang paling ringan dan jumlah biji setiap polong yang tidak terlalu banyak tetapi pada setiap tanaman menghasilkan polong dalam jumlah yang lebih banyak sehingga setiap tanaman menghasilkan biji kering yang paling berat. 


\begin{tabular}{lccc}
\multicolumn{1}{c}{ Parameter } & \multicolumn{3}{c}{ Varietas Kedelai } \\
\cline { 2 - 4 } & Davros & Willis & Lokal \\
\hline Tinggi Tanaman 25 HST (cm) & 12,4 & 27,0 & 19,0 \\
Tinggi Tanaman 50 HST (cm) & 26,8 & 47,1 & 42,4 \\
Tinggi Tanaman 75 HST (cm) & 29,3 & 50,1 & 45,6 \\
Diameter Batang 25 HST (mm) & 0,12 & 0,17 & 0,15 \\
Diameter Batang 50 HST (mm) & 0,46 & 0,63 & 0,56 \\
Diameter Batang 75 HST (mm) & 0,48 & 0,64 & 0,58 \\
Luas Daun (cm ${ }^{2}$ ) & 205,9 & 224,4 & 269,4 \\
Jumlah Polong Per Tanaman & 10,9 & 13,9 & 19,7 \\
Jumlah Biji Per Polong & 1,9 & 2,1 & 1,9 \\
Berat Kering Biji Per Tanaman (g) & 15,6 & 16,4 & 24,7 \\
Berat Kering 100 Biji (g) & 9,3 & 9,5 & 8,7 \\
Berat Kering Biji Per Petak (t/ha) & 0,025 & 0,031 & 0,044 \\
Berat Segar Berangkasan (t/ha) & 0,031 & 0,043 & 0,044 \\
Berat Kering Berangkasan (t/ha) & 0,010 & 0,030 & 0,030 \\
Indeks Panen (\%) & 64,5 & 55,6 & 60,1 \\
\hline
\end{tabular}

\section{Simpulan}

Dari analisis hasil dan pembahasan yang dilakukan maka disimpulkan beberapa hal sebagai berikut:

a. Tidak terjadi pengaruh interaksi antara takaran pupuk kandang sapi dan varietas kedelai terhadap semua parameter yang diamati.

b. Takaran pupuk kandang sapi berpengaruh secara nyata terhadap suhu tanah 75 HST, kadar lengas 50 HST, diameter batang 25 HST, jumlah biji per baris, berat kering 100 biji, berat kering biji per petak dan indeks panen. Varietas kedelai berpengaruh secara nyata terhadap jumlah baris per bulir, jumlah biji per baris danberat kering biji per petak.

c. Pupuk kandang sapi $40 \mathrm{t} / \mathrm{ha}$ merupakan takaran yang lebih baik dan kedelai varietas Lokal lebih cocok untuk ditumpangsarikan dengan jagung.

\section{Pustaka}

Anonim, 2005. Kadar Lengas Tanah.A nonim A [Diakses 12 Mei 2015]. [tersedia pada http://missouryuniversity.com].

BPS:[Badan PuastBagian Tanaman Pangan Statistik]. 2011. NTT dalam angka. Kefamenanu.

Dinas Pertanian Tanaman Pangan. 2010. Pemasaran Dalam Mendukung Peningkatan Produksi Tanaman Pangan. Dinas Pertanian Tanaman Pangan Provinsi NTT.

Gomez K A dan Gomez A A. 1995. Prosedur Statistik untuk Penelitian Pertanian, Edisi ke 2. UI Press. Jakarta.

Herlina. 2011. Kajian Variasi Jarak dan Waktu Tanam Jagung Manis Dalam Sistem Tumpangsari Jagung Manis (Zea mays saccarata Sturt ) dan Kacang Tanah (Arachis hypogeal L.). [Tesis]. Pogram Pascasarjana Universitas Andalas. Padang.

Hsieh, S.C, Hsieh C. F. 1990. The use of organic matter in crop production. Paper Presented at Seminar on "The Use of Organic Fertilizer in CropProduction “ at Soweon.South Korea. 18-24 June 1990.

Jumin, H. B. 1997. Dasar-dasar Agronomi. Raja Grafindo Persada. Jakarta.

Nasution, M. 2004. Diversifikasi Titik Kritis Pembangunan Pertanian Indonesia. Pertanian Mandiri. Penebar Swadaya. Jakarta.

Noor, A. dan Ningsih, R.D. 1998. Upaya meningkatkan kesuburan dan produktivitas tanah di lahan kering. Dalam. Prosiding Lokakarya Strategi Pembangunan Pertanian Wilayah Kalimantan. Instalasi Penelitian dan Pengkajian Teknologi Pertanian. Banjarbaru.

Poerwowidodo. 1995. Metode Selidik Tanah. Usaha Nasaional.Surabaya

Suprapto, H. 1998. Bertanam kedelai. Swadaya. Jakarta.

Taufiq, T.M.M. dan Novo. I. 2004. Kedelai, Kacang Hijau dan Kacang Panjang. Absolut Press. Yogyakarta.

Warsono, R. 1998.Pengolahan lahan kering. Makalah yang disampaikan pada SeminarNasional II Bididaya Lahan Kering. Dalam rangka Dies Natalis XV Unhalu. Kendari. 